Матеріали науково-практично конференці з участю міжнародних спеціалістів «Актуальні питання діагностики, лікування, раціонально фармакотерапі , диспансеризаці та реабілітаці в практиці сімейного лікаря»

\title{
СТАН ДЕТОКСИКАЦІЙНО ФУНКЦІ ПЕЧІНКИ У ХВОРИХ ІЗ ЗАПАЛЬНИМИ ЗАХВОРЮВАННЯМИ КИШКИ
}

\author{
(Р. І. Яцишин, Н. В. Скробач, В. О. Петрина, О. А. Шаповал, В. Ю. Вишиванюк \\ ДВНЗ «/вано-Франківський національний медичний університет»
}

\begin{abstract}
Запальні захворювання кишки (З3К) характеризуються рецидивуючим перебігом з тривалими загостреннями і ускладненнями, які зумовлюють втрату працездатності хворих. Не викликає сумнівів, що супутні дисбіотичні зміни кишки погіршують перебіг основного захворювання, частіше настають рецидиви та розширюються варіанти ускладненого перебігу, можуть спостерігатися патологічні зміни печінки різного ступеня тяжкості.

Мета дослідження. Оцінити стан детоксикаційно функці печінки у хворих на З3К за допомогою використання ${ }^{13} \mathrm{C}$-метацитинового дихального тесту.

Матеріали і методи. Обстежено 54 хворих на 33К, які перебували на лікуванні в гастроентерологічному відділенні Івано-Франківсько ОКЛ. Серед обстежених хворих було 57 \% чоловіків та $43 \%$ жінок, середній вік склав $(46,85 \pm 1,10)$ року, а тривалість $33 \mathrm{~K}-(5,94 \pm 0,33)$ року. Пацієнтам проводили бактеріологічне дослідження калу та ${ }^{13} \mathrm{C}$-метацитиновий дихальний тест $\left({ }^{13} \mathrm{C}-\mathrm{MДT}\right)$.

Результати й обговорення. При проведенні бактеріологічного дослідження калу у всіх хворих спостерігали зменшення кількості біфідобактерій, у 94,4\% хворих - лактобактерій, а в 68,5 \% хворих
\end{abstract}

відмічалося зростання кількості кишково палички, зі збільшенням штамів із гемолізуючою та зниженою ферментативною активністю, патогенних мікроорганізмів не було. Дисбіоз І ступеня, що характеризувався зменшенням біфідобактерій і лактобактерій до рівня $10^{7}-10^{6} \mathrm{KУO/г} \mathrm{спостерігали} \mathrm{в} 35$ $(64,8 \%)$ хворих. Зниження біфідобактерій до рівня $10^{4}-10^{3} \mathrm{KУО} / г$ та лактобактерій до $10^{6}-10^{5}$ із одночасним дисбалансом у кількості та якості кишково палички виявлено в 19 (35,2 \%) пацієнтів (дисбіоз II ступеня). Згідно з отриманими даними, середній показник сумарно концентраці ${ }^{13} \mathrm{CO}_{2}$ через 120 хв у пацієнтів із дисбіозом II ступеня в середньому становив $(19,41 \pm 0,52) \%$ та був нижчим на $23,7 \%$ від рівня в практично здорових осіб - $(25,46 \pm 0,67) \%$ $(\mathrm{p}<0,05)$.

Висновок. Дисбіоз посилює запальний процес у стінці кишки, сприяе підвищенню проникності слизово оболонки, переміщенню бактеріальних ендотоксинів у системне русло та призводить до зниження детоксикаційно функці печінки. Рекомендовано широко застосовувати ${ }^{13} \mathrm{C}-\mathrm{MДТ} \mathrm{у} \mathrm{клінічній} \mathrm{практиці}$ як додатковий метод встановлення функціонального стану печінки, для оцінки ефективності лікування та прогнозування перебігу захворювання. 